Indian J. Anim. Hlth. (2019), 58(2) -Special Issue: 121-136

DOI: https://doi.org/10.36062/ijah.58.2SPL.2019.121-136

Review Article

\title{
ANTIBIOTICS AS FEED ADDITIVES FOR LIVESTOCK: HUMAN HEALTH CONCERNS
}

\author{
T. K. DUTTA*, S. K. YADAV AND A. CHATTERJEE \\ ICAR- National Dairy Research Institute \\ Estern Regional Station \\ Kalyani 741 235, West Bengal, India
}

\begin{abstract}
Antibiotics are defined as a category of natural, semi-synthetic or chemical compound with anti-microbial activity, which is extensively used to control and prevent for infectious diseases in animals and humans, and may be added in the feed as growth promoters to promote the growth and development of animals. Until recently, the main concern about inclusion of antibiotics as supplements in animal feeds is connected to antibiotic residues in products (milk, egg and meat) developed from the treated animals. These residues may cause a range of side effects such as immunopathological effects, transfer of antibiotic resistant bacteria to humans, mutagenicity, allergy, hepatotoxicity, reproductive disorders, nephropathy, bone marrow toxicity and even carcinogenicity. One of the most significant adverse effect of antibiotic residues is the transfer of antibiotic resistant bacteria to the humans due to the mobile properties of resistance. The rising use of antibiotic consumption in India is reflected through emerging drug resistance problem and regulations for the use of antibiotics in animals and human are still very poor. The unnecessary use of antibiotics in food producing animals is contributing to the antibiotic resistance development in zoonotic bacteria. Because of these detrimental effects, it is essential to regulate the antibiotic use in food animals. Farmers and veterinary practitioners should be aware of the problem through education by authorities. Now-adays there are good number of alternatives to antibiotics use; such as probiotics, prebiotics, herbal additives, organic acids, enzymes, active plant metabolites etc. which may boost production performance and immunity of the livestock and poultry without any adverse effect.
\end{abstract}

Key words: Additives, Animal, Antibiotics, Humans, Resistance

\section{Introduction}

The word antibiotic means "against life". Antibiotics are defined as a category of natural, semi-synthetic or chemical compound with anti-microbial activity, which is extensively used to control and prevent for infectious diseases in animals and humans, and added in the feed as growth promoters to promote the growth and development of animals (WHO, 2015). The discovery of the beneficial effects of antibiotics as feed additive on growth promotion was accidental. The growth promoter effect of antibiotics was revealed in the 1940s. Once it was observed that animals fed dried mycelia of Streptomyces 
aureofaciens containing chlortetracycline residues enhanced their growth (Castanon, 2007) and within five years the addition of growth promoting antibiotics has become a common practice. Increasing antibiotic use is driving an increase in antibiotic resistance, in both humans and animals. Because resistant bacteria can be transmitted between humans and animals through contact, food products and the environment. More antibiotics are used in animal than in humans, more often to promote growth or prevent diseases than to treat sick animals (Center for Disease Dynamics, Economics \& Policy Report, 2016).

Poultry is one of the most widespread food industry worldwide and it is the fastest growing industry in India. Chicken is the most commonly farmed species, world poultry meat production soared from 9 to 120 million tonnes between 1961 and 2016, and egg production shot up from 15 to 81 million tonnes (FAO, 2016). A large diversity of antimicrobials are used to raise poultry in most countries (Landers et al., 2012; Sahoo et al., 2010; Boamah, et al., 2016). Antibiotic resistance (AR) is defined as the ability of an organism to resist the killing effects of an antibiotic to which it was normally susceptible (Madigan et al., 2014) and it has become an issue of global interest. This microbial resistance is not a new phenomenon since all microorganisms have an inherent capacity to resist some antibiotics (Hugo and Russel, 1998). Antibiotic feeding at sub-therapeutic levels in feed may leave antibiotic residues in foodstuffs such as milk, egg and meat.

In India also livestock farms/industries are using several antibiotics as feed additive/ growth promoter. These antibiotic residues may cause various toxic effects such as transfer of antibiotic resistant bacteria to humans, allergy, immuno-pathological effects, nephropathy (gentamicin), bone marrow toxicity (chloramphenicol), carcinogenicity (sulphamethazine, oxytetracycline, furazolidone), mutagenicity, hepatotoxicity, reproductive disorders and even anaphylactic shock in humans (Nisha, 2008; Darwish et al., 2013). The indiscriminate use of such essential antimicrobials in animal production is likely to accelerate the development of AR in pathogens, as well as in commensal organisms. This would result in treatment failures, economic losses and could act as source of gene pool for transmission to humans. In addition, there are also human health concerns about the presence of antimicrobial residues in meat (Mirlohi et al., 2013; Darwish et al., 2013), eggs (Goetting et al., 2011) and other animal products.

\section{Use of antibiotics in food animals as additives}

Antibiotics are widely used for therapeutic purpose, prophylactic measure and as growth promoter. The use of antibiotics in poultry and livestock production is considered favorable to farmers and the economy as well because it has generally improved poultry performance effectively and economically but at the same time, the likely dissemination of antibiotic resistant strains of pathogenic and non-pathogenic organisms into the environment and their further transmission to humans via the food chain could also lead to serious consequences on public health (Apata, 2009). Predominantly, the use of antibiotics as growth and feed enhancers is linked with economic gains. 
Table 1. Summary of antibiotics registered for use as growth promotants in Australia, the EU and the USA

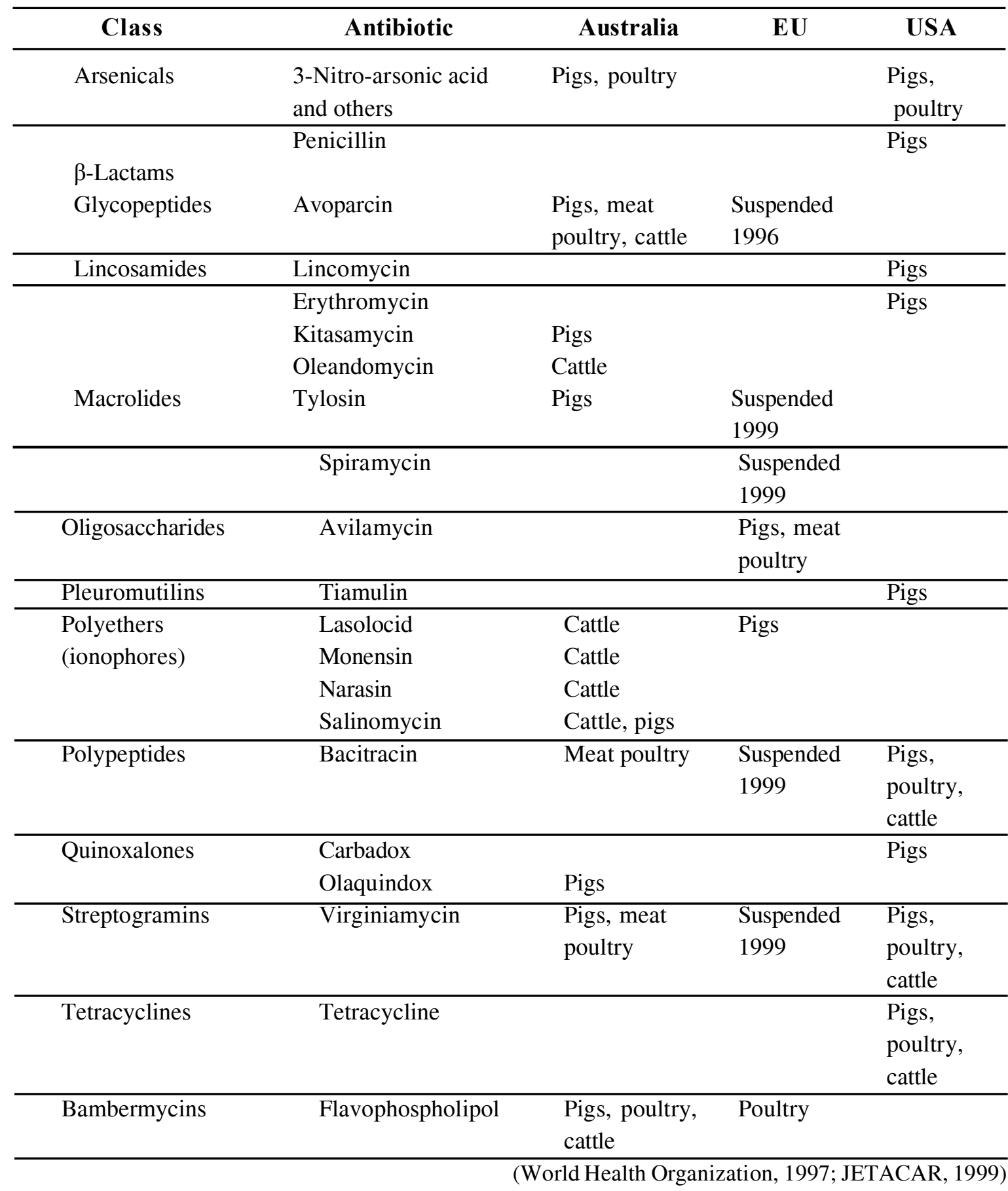


Van Boeckel et al. (2015) demonstrated ranking of antibiotics usage in food animal according to countries. With a percentage of $23 \%$ china is the first country in using antibiotics in food animals. The order of the other countries was as follows: United States (13\%), Brazil (9\%), India (3\%) and Germany (3\%). Zhang et al. (2015) reported that China consumed over 84200 tonnes of antimicrobials in food animal production in 2013, which suggests that China may be the largest consumer of antimicrobials in animal production in the world. According to an estimate, of the total antibiotics manufactured in the United States, about $60 \%$ to $80 \%$ are used as a feed additives for healthy animals in subtherapeutic concentrations (Mellon et al., 2001).

History: The growth promotant effect of low levels (sub-therapeutic) of antibiotics in animal was discovered in 1940 s, when it was observed that animal fed dried mycelia of Streptomyces aureofacience containing tetracycline residues improves their growth (Stokstad et al., 1949). The mechanism of action of antibiotics as growth promoters is connected to interactions with intestinal microbial population (Dibner and Richards, 2005; Niewold, 2007). Table-1 indicated the growth-promotant antibiotics resistered for use in USA, Europe and Austrelia. A less wider range is used in the Austrelia or Europe than USA. Swann Report (Swann, 1969) indicated the impact of antibiotic use of animals on human health and established the response to multidrug-resistant Salmonella in the 1960s; it concluded that growth promotion with antibiotic used for human therapy should be banned. One of the first ban on antibiotic growth promoter (AGP) use was that imposed on tetracycline by European Common Market in 1970s.
The main expected consequence of the ban is a decrease amount of antibiotics use in food animals production; therefore, the risk of antibiotic resistance transmission through food chain may be reduced. Prior available research data suggested that the growth promoter ban has driven an increase in infections and consequently, substantial enhanced in the use of therapeutic antibiotics for food animals in Europe, but the ban also decreased overall antibiotic use in animal (Casewell et al., 2003).

Benefits: Use of antibiotics in food production in animals was mainly for some benefits like well being of animals,quality and growth efficiency, feed efficiency enhancers, economic production, carcass quality and public health (Van Boeckel et al., 2015). Small doses of antibiotics could increase the rate of weight gain and 'feed efficiency' of animals which was first noted in the 1940s, and though the exact mechanism was not well understood, the practice gained widespread use soon after (Dibner and Richards, 2005). Most of the growth promotants are active against Grampositive organisms (Table-2).

Livestock is responsible for over a fourth of India's total agricultural output, and 4 percent of the gross domestic product (GDP). India is one of the top consumers of agricultural antibiotics worldwide, accounting for 3 percent of global consumption. By 2030, this use is estimated to double (Center for Disease Dynamics, Economics \& Policy Report, 2016). Van Boeckel et al. (2015) estimated that annually, $45 \mathrm{mg} / \mathrm{kg}, 148 \mathrm{mg} / \mathrm{kg}$ and $172 \mathrm{mg} / \mathrm{kg}$ antimicrobials are consumed to produce each kilogram liveweight of cattle, chicken, and pigs, respectively. In the United States, approximately 80 percent of all antibiotics 
Table 2. Antibacterial activity of growth promotant antibiotics

\begin{tabular}{lll}
\hline Class of antibiotic & $\begin{array}{l}\text { Commonly used growth } \\
\text { promotants }\end{array}$ & \multicolumn{1}{l}{ Mode of action } \\
\hline Arsenicals & 3-Nitro-arsonic acid & DNA effects? \\
\hline$\beta$-Lactams & Penicillin G & Gram-positive cell-wall synthesis \\
\hline Glycopeptides & Avoparcin & Gram-positive cell wall synthesis \\
\hline Lincosamides & Lincomycin & $\begin{array}{l}\text { Inhibit protein synthesis in Gram-positive } \\
\text { bacteria }\end{array}$ \\
\hline Macrolides & $\begin{array}{l}\text { Erythromycin, tylosin, } \\
\text { kitasamycin,oleandomycin } \\
\text { spiramycin }\end{array}$ & $\begin{array}{l}\text { Inhibit protein synthesis, principally in } \\
\text { Gram-positive bacteria }\end{array}$ \\
\hline Oligosaccharides & Avilamycin & $\begin{array}{l}\text { Inhibit protein synthesis in Gram- } \\
\text { positivebacteria }\end{array}$ \\
\hline Pleuromutilins & Tiamulin & As for macrolides \\
\hline Polyethers & Monensin, lasolocid, & $\begin{array}{l}\text { Affect bacterial cell permeability, active } \\
\text { against Gram-positive bacteria }\end{array}$ \\
\hline Polypeptides & Bacitracin & Gram-positive cell-wall synthesis \\
\hline Quinoxalones & Carbadox, olaquindox & $\begin{array}{l}\text { Inhibit bacterial DNA synthesis and } \\
\text { denature pre-existing DNA; } \\
\text { activeagainst anaerobes }\end{array}$ \\
\hline $\begin{array}{ll}\text { Streptogramins } \\
\text { positive }\end{array}$ & Virginiamycin & $\begin{array}{l}\text { Inhibit protein synthesis in Gram- } \\
\text { bacteria }\end{array}$ \\
\hline Tetracyclines & Tetracycline & $\begin{array}{l}\text { Inhibit protein synthesis; broad spectrum } \\
\text { Bambermycins }\end{array}$ \\
Flavophospholipol & $\begin{array}{l}\text { Interferes with cell wall synthesis in } \\
\text { Gram-positive bacteria }\end{array}$ \\
\hline
\end{tabular}

consumed are used in the livestock sector (Food and Drug Administration, 2010). The amount of antibiotics given to animals for nontherapeutic reasons, including prophylaxis (also referred to as 'metaphylaxis') and growth promotion (AGPs), far outstrips the volume used to treat disease, though exact figures are lacking (Center for Disease Dynamics, Economics \& Policy Report, 2016).

Antibiotic growth promoter are used to
(Barton, 2000)

improve productivity and enhanced economic returns to farmers (Taylor, 1999). Antibiotic growth promotants(AGPs) have been shown to constantly improve feed efficiency and body weight gain in growing pigs, specifically during the nursery phase (Gaskins et al., 2002). Previous research showed improvements on growth rate and feed conversion in piglets of $9 \pm 30 \%$ and $6 \pm 12 \%$, respectively (Thomke and Elwinger, 1998) due to use of antibiotics as growth 
promoter. The stressors (separation from the sow, re-mixing and changes in diet) compromised the immune system of the pigs (Campbell et al., 2013), making pigs more vulnerable to infectious agents.One of the simplest ways of tackling this problem is thepractice of prophylactic antibiotics administered via the feed which is the simple way of avoiding the risk of disease in weaned pig. The use of antibiotics as growth promoters in poultry has been widely practiced in the poultry industry since early 1950's (Markovic et al., 2009; Eseceli et al., 2010). Currently, there is controversy surrounding the use of antibiotic growth promoters due to increased public concern over the adverse and undesired residues in animal products i.e., meat, milk, eggs and the development of resistance in microorganisms and the harmful effects on human health. Many studies have shown no weight gain difference in broilers fed an AGP diet in the absence of health problems (Denev, 2006; Naveen et al., 2017).

Antibiotic growth promoter improved broiler growth performance and reduce the populations of potentially-pathogenic organisms such as Clostridium perfringens, Salmonella and E. coli (Hume, 2011). However, the risk of developing crossresistance and multiple antibiotic resistance in human pathogenic bacteria, which could result in proliferation of antibioticsinsensitive bacteria, has led to the ban or severe limitations of the use of antibiotic growth promoter in many countries. Antibiotics as growth promoters have been banned in the European Union since January 1, 2006 (Castanon, 2007) to reduce the development of antibiotic resistance and transfer of these genes from animal to human beings
Ionophores (such as monensin, lasalocid, laidlomycin, salinomycin and narasin) are antimicrobial compounds that are commonly fed to ruminant animals to improve feed efficiency. In cattle, monensin has been marketed as a propionate (the most efficiently utilized gluconeogenic VFA) enhancer and methane inhibitor (Dinius et al., 1976; Tedeschi et al., 2003). By the treatment of monensin the ruminal methane production is decreased by $30 \%$ (Johnson and Johnson, 1995). Many propionateproducing ruminal bacteria like Selenomonas ruminantium, Megasphaera elsdenii are not inhibited by monensin (Callaway and Russell, 1999). Additional benefits of monensin usage include a reduction of dietary protein deamination, ensuing in less ammonia urinary excretion (Russell and Strobel, 1989) and reduction in lactic acid production (Dennis et al., 1981) which results decrese in liver abscesses (Nagaraja and Chengappa, 1998) and ruminal acidosis (Russell and Strobel, 1989). The increse in nitrogen retention and energy avalibility improve the efficiency of feed utilization by the ruminant animal and thus enhanced animal productivity and production profitability due to monensin addition (Russell and Strobel, 1989). A recent study by Gupta et al. (2019) concluded that monensin supplementation at $0.6 \mathrm{mg} / \mathrm{kg}$ body weight in growing heifers enhanced feed efficiency and daily gain while it reduced enteric methane production which can reduce feedlot time and consequent life time $\mathrm{CH}_{4}$ production.

Problems associated with antibiotic use in animals

Antibiotic residues: European Union (EU) defines residues as "pharmacolog-ically 
active substances (whether active principles, recip-ients, or degradation products) and their metabolites which remain in foodstuffs obtained from animals to which the veterinary medicinal products in question have been administered". Antibiotic residues in foodstuff is a serious concern because of the possible threat to human health.

Allergic reactions (penicillin) are one of the most adverse effects of antibiotics in food. The bulk of information is related to hypersensitivity of penicillin, aminoglycosides and tetracyclines (Katz and Brady, 2000). Unfortunately, the long term effects of antibiotics on human health have not been known yet. Prior research suggested $\beta$-lactams as less toxic antibiotics. However, the literature review shows that they were responsible for the most of reported allergic reactions due to antimicrobials in humans (Davies and Davies, 2010). Idiosyncratic reactions like skin rashes, allergy and phototoxic dermatitis have been reported depending on the use of tetracyclines (Yates and deShazo, 2003). Presence of low level of antibiotic residues in milk, meat and egg causes microorganism to be resistant against antibiotics.Other pathological conditions reported are immuno-pathological effects, carcinogenicity (sulphamethazine, oxytetracycline, furazolidone), mutagenicity, teratogenicity, disturbances in the normal intestinal environ-ment, nephropathy (Gentamicin), hepatotoxicity, bone marrow toxicity (chloramphenicol) and various reproductive disorders (Nisha, 2008).

Only a small proportion of animal derived foods are consumed as raw food; therefore, cooking and freezing process are very important for reduction of antibiotic residue in food (Katz and Brady, 2000). However these processes are not enough for removal of antibiotics residue. The heat treatment of animal foods may inactivate antibiotics (Darwish et al., 2013). Many studies reported that degradation of quinolones, $\beta$ lactams, macrolides, aminogycosides, sulphonamides and tetracyclines are temperature dependent and prolonged heating time helps to induce more degradation (Tian et al., 2017). UV irradiation, resin and activated charcoal might be beneficial in antibiotic inactivation (Nisha, 2008).

Antibiotic Resistance: One primary problem with use of antibiotic in intensive livestock systems is that it has been related with antibiotic resistance (ABR). Uncontrolled use of antibiotics has led to loss of efficacy of the antibiotics known as "Antibiotic Resistance (ABR)". Antibiotic resistance has been defined as "the capacity of an organism to resist the killing effects of an antibiotic to which it was earlier susceptible." In simple terms, this means that infectious diseases which were once easily curable can now prove to be fatal due to the transmission of resistant microbes among the individual via direct contact or indirectly by exchange of resistant genes in the envi-ronment (Mahalmani et al., 2019). WHO (2014) has declared it a risk for both human and animal health. European Union has applied ban of antibiotics as growth promoters in 2006 and this ban was important in reducing antibiotics use. Some authors have also suggested that withdrawal of prophylactic antibiotics is not necessarily related with negative effects on production (Postma et al., 2017). European Food Safety Authority (EFSA) recommends that bacterial strains harboring transferable antibiotic 
resistance genes should not be used in animal feeds, fermented and probiotic foods for human use (EMA and EFSA Reort, 2017). A major global public health issue is emergence of ABR along the food chain,with prior research suggests that food animals and products being colonized and/ or infected and contaminated by antibioticresistant strains; such as antibiotic-resistant Campylobacter spp. (Ewnetu and Mihret, 2010), methicillin-resistant Staphylococcus aureus (MRSA) (Price et al., 2012), and extended spectrum- beta-lactamase (ESBL) producing-Enterobacteriaceae (viz. Salmonella spp., Shigella spp., Klebsiella spp., Escherichia coli, etc.; Fischer et al., 2012; Al Bayssari et al., 2015). Currently, some countries still use antibiotic as growth promoter without strict regulatory mechnism.

\section{Emergence of antibiotic resistance in}

India: India is a developing country where factors such as poor sanitation, poor nutrition, and overcrowding are the main causes for the development of infections; and therefore, there is a extensive use of a large number of antimicrobials to raise the poultry. Misuse of antibiotics in poultry farms is leading to a proliferation of multi-drug resistant bacteria. To make matters worse, these bacteria are now spreading in the environment because of unsafe disposal of poultry litter and waste in agricultural fields - this has a potential to infect human beings: says a new study from Centre for Science and Environment (CSE), 2017). The study conducted by CSE's Pollution Monitoring Laboratory, collected samples of litter and soil from in and around 12 randomly selected poultry farms. These were located in four key poultry-producing states in North India - Uttar Pradesh, Haryana, Rajasthan and Punjab. A total of 217 isolates of three types of bacteria - E. coli, Klebsiella pneumonieae and Staphylococcus lentus were extracted and tested for resistance against 16 antibiotics. Ten of these antibiotics have been declared Critically Important (CI) for humans by the World Health Organization (WHO). The study further exposed that $100 \%$ of the E. coli, $92 \%$ of $K$. pneumoniae and $78 \%$ of $S$. lentus isolated were found to be multidrug resistant. The conclusion of results was that poultry farms are reservoirs of multi-drug resistant bacteria and that resistance is moving from farms to agricultural fields in the case of E.coli. This showed that multi-drug resistant $E$. coli produced in the poultry were gaining entry into the environment through litter (Khurana et al., 2017). Samples of raw food were taken from different parts of a metropolitan city (Chennai) in India. Out of 110 samples in total, $46.4 \%$ had colistin resistance organisms (Ghafur et al., 2019).

Tuberculosis (TB) has also become one of the biggest health issues in India. A study conducted by Qumar et al (2017) in Hyderabad on Helicobacter pullorum isolates found that free range and broiler chickens were resistant to different antibiotics such as fluoroquinolones, cephalosporins, sulfonamides and macrolides. Therefore, use of animal food containing such resistant drugs would certainly cause a interference in the therapy of TB as some of these drugs are second-line drugs in TB therapy.

Microbes such as carbapenem resistant Enterobacteriaceae and methicillin resistant Staphylococcus aureus (MRSA) have become a global problem. The rising use of antibiotic consumption in India is reflected through emerging drug resistance problem 
and regulations for the use of antibiotics in animals and human are still very poor.

\section{Regulatory control to use antibiotics}

The American Medical Association, the World Health Organization (WHO) and the American Public Health Association have urged a ban on growth promoting antibiotics arguing that their use leads to various health problems in humans (Graham et al., 2007). Between 1st January 2014 and 31st December 2016, the FDA implemented a voluntary plan with the pharmaceutical industry to phase out the use of antibiotic growth promoters (FDA, 2013). However, the evidence so far is that farmers may switch to using more antibiotics for routine disease prevention and control, as occurred in the European Union when growth promoters were phased out between 1997 and 2006. In contrast, routine preventative mass medication is no longer practiced in the Nordic countries (Denmark, Finland, Iceland, Norway and Sweden) and the Netherlands, demonstrating that such practices are not necessary. The United States Department of Agriculture published an Antimicrobial Resistance Action Plan in 2014 (USDA, 2014). However, the action plan lacks serious ambition and does not include any proposals to ban routine preventative use, nor to introduce targets for reducing antibiotic use nor even to collect nationwide statistics on actual farm antibiotic use. The National Antimicrobial Resistance Monitoring System for Enteric Bacteria (NARMS), established in 1996, is a collaboration among state and local public health departments, CDC, the U.S. Food and Drug Administration (FDA), and the U.S. Department of Agriculture (USDA). This national public health surveillance system tracks changes in the antimicrobial susceptibility of certain enteric (intestinal) bacteria found in ill people (CDC), retail meats (FDA), and food animals (USDA) in the United States.

Most of the developed countries have banned the use of certain antibiotics in agriculture. Legislation regarding the control of antibiotic residues in animals and their products were given in European Union (EU) Council Directive 96/23/EC (EC, 2012). Subtherapeutic doses of antibiotic usage in food animals has been banned in the EU countries. In 1985, the use of antibiotic in animal feed was banned in Sweden. The use of avoparcin in Denmark was prohibited in 1995, followed by a ban on virginiamycin in 1998. Four growth promoters (zinc bacitracin, virginiamycin, tylosin phosphate and spiramycin ) and avoparcin was banned by EU in 1997. In 1998 the use of all antimicrobials for growth promotion was stopped by Danish Food Industry (Willis, 2000). In 2005, use of enrofloxacin in food animals was banned by Food and Drug Administration (FDA), USA due to the increased levels of fluoroquinolone-resistant Campylobcter sp (Huyghebaert et al., 2011). Against legal prohibitions on use of antibiotics in many countries, still wide use of most of the antibiotics is going on for promotion of growth and treatment or prevention of diseases (Muaz et al., 2018). It is estimated that antibiotics utilization will increase by $67 \%$ within 2030, and almost twice this increase in countries such as India, China, Brazil, South Africa and Russia (Van Boeckel et al., 2015).

The Feed Additives Regulation completed measure with the total ban on antibiotics as growth promoters from January 1, 2006. The following 4 substances were removed from the EU Register of permitted feed additives: 
Table 3. Recommendations/Policy by organizations to address the use of antibiotics and antibiotics resistance in livestock, poultry and fisheries sectors in India

\begin{tabular}{|c|c|c|}
\hline Year & Organizations & Recommendations/proposals \\
\hline 2007 & $\begin{array}{l}\text { BIS-Poultry feed } \\
\text { recommendation } \\
\text { BIS (2007) }\end{array}$ & $\begin{array}{l}\text { Stop use of antibiotic growth promoters with systemic action } \\
\text { in poultry feed such as chloramphenicol, doxycycline, } \\
\text { tetracycline, nitrofurazone and furazolidone.Stop usage of gut } \\
\text { acting antibiotics in five years. }\end{array}$ \\
\hline 2011 & $\begin{array}{l}\text { National Policy on } \\
\text { containment of AMR } \\
\text { (NPCAR, 2011) }\end{array}$ & $\begin{array}{l}\text { Action plan includes enforcement and enhancement of } \\
\text { regulatory provision on antimicrobials usage in poultry sector, } \\
\text { along with necessary labelling in food.Promote rational use } \\
\text { of drugs via education and managerial and regulatory } \\
\text { strategy.Advocate the strengthening of diagnostics for AMR } \\
\text { monitoring. }\end{array}$ \\
\hline $2012-2017$ & $\begin{array}{l}\text { National Programme } \\
\text { on Containment of } \\
\text { AMR (NPCAR, 2012) }\end{array}$ & $\begin{array}{l}\text { Aimed at laboratory-based AMR surveillance system. } \\
\text { Strengthen infection control guidelines.Generate awareness } \\
\text { among healthcare providers. }\end{array}$ \\
\hline 2013 & $\begin{array}{l}\text { Drug Controller } \\
\text { General of India } \\
\text { (2013) Drugs and } \\
\text { Cosmetics Act }\end{array}$ & $\begin{array}{l}\text { Directed the drug manufacturers about administration of } \\
\text { antibiotics and their withdrawal period for food-producing } \\
\text { animals.Compulsory labelling of withdrawal periods on } \\
\text { antibiotics intended for animal use; If this period is not } \\
\text { validated, then use following period 'egg or milk (seven days), } \\
\text { poultry meat ( } 28 \text { days)'. }\end{array}$ \\
\hline 2013 & $\begin{array}{l}\text { National Livestock } \\
\text { Policy (2013) }\end{array}$ & $\begin{array}{l}\text { Encouraged States to promote judicious use of antibiotics; } \\
\text { however, barely touched antibiotic resistance issue. }\end{array}$ \\
\hline 2014 & $\begin{array}{l}\text { DAHD (2014) } \\
\text { Department of Animal } \\
\text { Husbandry, Dairying } \\
\text { and Fisheries, Circular } \\
\text { to States }\end{array}$ & $\begin{array}{l}\text { Requested States to advise veterinarians and feed } \\
\text { manufacturers about judicious antibiotics use for treatment } \\
\text { of ailing food-producing animals, and to stop antibiotics use } \\
\text { in feed. }\end{array}$ \\
\hline 2015 & FSSAI (2015) & $\begin{array}{l}\text { Suggested veterinary supervision during antibiotics use on } \\
\text { animals. Feed for meat producing animals or birds should } \\
\text { not include meat, blood meal, bone tissues except milk and } \\
\text { milk products. Suggested different slaughterhouses for poultry } \\
\text { and livestock animals. Strictly banned AGPs in poultry and } \\
\text { meat. Supply licensed antibiotics for tracking antibiotic use. }\end{array}$ \\
\hline $2017-2022$ & $\begin{array}{l}\text { National Policy on } \\
\text { Containment of AMR } \\
\text { (NPCAR, 2017) }\end{array}$ & $\begin{array}{l}\text { To provide better awareness and AMR understanding by } \\
\text { various trainings, learning and communication.Effective } \\
\text { surveillance.Emphasis on infection prevention and } \\
\text { control.Primarily focuses on resistance in bacteria. }\end{array}$ \\
\hline \multicolumn{3}{|l|}{ Aquaculture } \\
\hline 2011 & FSSAI (2011) & $\begin{array}{l}\text { Tolerance limit for four antibiotics (tetracycline, } \\
\text { oxytetracycline, trimethoprim and oxolinic acid) was set for } \\
\text { seafoods (shrimps, prawns) and a variety of fish and related } \\
\text { products.Ban of several antibiotics as well as other } \\
\text { pharmacologically active substances. }\end{array}$ \\
\hline
\end{tabular}


- Monensin sodium used for cattle for fattening

- Salinomycin sodium used for piglets and pigs fattening

- Avilamycin used for piglets, pigs for fattening, chickens for fattening and turkey

- Flavophospholipol used for rabbits, laying hens, chickens for fattening, turkeys, piglets, pigs, calves and cattle for fattening

In recent years focus on overcoming the problems of antibiotics resistance has become one of the priority areas of legislation authorities. A list of antibiotics has been published by WHO which cannot be used in animals. Cephalosporins, macrolides, polymyxins, gycopeptides and quinolones are in the list of critically important antibiotics (Muaz et al., 2018).

Regulations in India: Ministry of Health and Family Welfare, Government of India have framed a comprehensive policy, namely, National policy for containment of antimicrobial resistance, 2011 to address the growing problem of multi-drug resistance. The Food Safety and Standards Authority of India (FSSAI), which defined standards for fisheries products through the Food Safety and Standards Regulations (FSSAI, 2011) has amended this regulation in 2017 to include standards for all food-animal products. Under the proposed Food Safety and Standards (Contaminants, Toxins and Residues) Amendment Regulation 2017 the tolerance limit of antibiotics and pharmacologically active substances in food of animal origin will be clearly specified to ensure antibiotic residue in food from animals does not threaten human health. The amended regulation states that for a list of 21 antibiotics the tolerance limit, used in human beings and animals will be $0.01 \mathrm{mg} /$ $\mathrm{kg}$ for the following types of foods namely: (i) All edible animal tissue; (ii) Fats derived from animal tissues and (iii) Milk. The amendments prescribe the maximum permissible limits of 21 antibiotics and 77 other veterinary drugs for use in food-animal production. Unfortunately, none of these recommendations have been formalized as laws so far.

Compared to other food-animal production sectors, there are many more rules and standards governing antimicrobial use in aquaculture production, especially because they are meant for exports. The Government of India's Marine Products Export Development Authority (MPEDA) regulates aquaculture production, which includes shrimp. MPEDA has set up 19 ELISA screening laboratories at various centers in the maritime states of India to conduct the pre-harvest testing/screening of the aquaculture products (shrimp/fish) for the presence of antibiotics residues like chloramphenicol and nitrofuran metabolites before the produce is harvested. The MPEDA's list of 20 antibiotics and pharmacologically active substances banned for use in aquaculture include: chloramphenicol, nitrofurans (including: furaltadone, furazolidone, furylfuramide, nifuratel, nifuroxime, nifurprazine, nitrofurantoin, nitrofurazone), neomycin, nalidixic acid, sulphamethoxazole, Aristolochia spp and preparations thereof, chloroform, chlorpromazine, colchicine, dapsone, dimetridazole, metronidazole, ronidazole, ipronidazole, other nitroimidazoles, clenbuterol, diethylstilbestrol (des), sulfonamide drugs (except approved sulfadimethoxine, sulfabromomethazine and sulfaethoxypyridazine), fluroquinolones and glycopeptides.

The veterinary health certificate required for 
exports is issued by Government of India's Export Inspection Council (EIC) under Ministry of Commerce and Industry. The EIC regulates establishments that process fish and fishery products meant for export and also regulates traceability and antibiotic residue for shrimp products. The Council also monitors antibiotic residues in eggs, honey, milk and poultry meat, meant for export. In 2002, new restrictions were placed for antibiotic residue levels in fresh, frozen, and processed fish and fishery products intended for export. The amendment includes maximum residue limits for tetracycline, oxytetracycline, trimethoprim, and oxolinic acid, and it prohibits the use of certain antibiotics in units processing all types of seafood. In 2003, through an amendment to an existing law regulations were introduced on antibiotic residues in eggs and egg products. In 2003, order S.O. 1227(E) prohibited the use of 'antibacterial substances, including quinolones' from the culture of, or in any hatchery for producing the juveniles or larvae or nauplii of, or any unit manufacturing feed for, or in any stage of the production and growth of, shrimps, prawns or any other variety of fish and fishery products without authorization from qualified veterinary surgeons or fishery scientists. In addition, this order bans the following antibiotics from feed, treatment, or use in any stage of production of egg powder for export: chloramphenicol, dimetridazole, metronidazole, nitrofurans, including metabolites of furazolidone and nitrofurazone.

\section{Conclusions}

Antibiotics have been used worldwide as feed additives/growth promoters in the livestock and poultry sectors. Contamination of meat, milk and egg with antibiotics is an important health hazard to the consumers. In human medicine antibiotic resistant human pathogens are a major challage. Use of antibiotics in food-producing animals has the potential to generate residues in animal products. The most probable reason for antibiotic residues may results from management, such as improper usage, illegal or extra-lebel antibiotic application.There is limited information on level of antibiotics residue worldwide. It has to be noted that, antibiotics in foodstuffs may be inherently toxic and may have an accumulative effect. Controls on antibiotic use in animals will not only resolve the present problems in human medicine,but may well help to increase the useful life of new class of antibiotics. It is also necessary to strengthen the segregation of antibiotics into those approved for animal use and those for human use. All new antibiotics uses in animal feed should be assessed before licensing for their potential to cause harm to human health and be strongly regulated. Antibiotic use in food animal production constitutes a major contributing factor to antibiotic resistance and thus there should be more research and application on alternative to antibiotic use in food animals. In recent years focus on overcoming the problems by antibiotics resistance has become one of the priority areas of legislation authorities in different countries including India. In order to conserve effectiveness of antibiotics in humans and animals, we have to track rates of veterinary antibiotic use, resistance, and residues through a nationwide surveillance and monitoring system; educate farmers, veterinarians and consumers on the dangers of antibiotic resistance; and phasing out the sub-therapeutic use of antibiotics in animals. Now-a-days there are good number of alternatives to antibiotics use; such as probiotics, prebiotics, herbal additives, essential oils, enzymes, active plant metabolites etc. which may boost production performance and immunity of the livestock and poultry. 


\section{REFERENCES}

Apata DF, 2009. Antibiotic resistance in poultry. Inter J Poultry Sci, 8: 404-408

Al Bayssari C, Dabboussi F, Hamze $M$ and Rolain JM, 2015. Emergence of carbapenemaseproducing Pseudomonas aeruginosa and Acinetobacter baumannii in livestock animals in Lebanon. J Antimicrob Chemoth, 70: 950-951

Barton MD, 2000. Antibiotic use in animal feed and its impact on human health. Nutr Res Rev, 13: 279-299

BIS, 2007. Indian Standard, Poultry Feeds Specifications. $5^{\text {th }}$ Revision, Bureau of Indian Standards, New Delhi IS1374

Boamah VE, Agyare C, Odoi H and Dalsgaard A, 2016. Antibiotic practices and factors influencing the use of antibiotics in selected poultry farms in Ghana. J Antimicrob Agents, 2: 120, doi: 10.4172/2472-1212.1000120

Callaway TR and Russell JB, 1999. Selection of a highly monensin-resistant Prevotella bryantii subpopulation with altered outer membrane characteristics. Appl Environ Microbiol, 65: 4753-4759

Campbell JM, Crenshaw JD and Polo J, 2013. The biological stress of early weaned piglets. J Anim Sci Biotechnol, 4: 19-25

Casewell M, Friis C, Marco E, McMullin P and Phillips I, 2003. The European ban on growthpromoting antibiotics and emerging consequences for human and animal health. $\mathrm{J}$ Antimicrob Chemoth, 52: 159-161

Castanon JIR, 2007. History of the use of antibiotic as growth promoters in European poultry feeds. Poult Sci, 86: 2466-2471

Center for Disease Dynamics, Economics \& Policy Report, 2016. Wasinton DC, 20005, USA

CSE (Centre for Science and Environment), 2017. Report on antibiobtics misuse in poultry farms leading to multi-drug resistant bacteria (www.cseindia.org/antibiotic-misuse)

DAHD, 2014. Department of Animal Husbandry, Dairying and Fisheries, Circular to States (http://www.farmer.gov.in/dadf/Advisories/ Advisory_on_use_of_antibiotics_in_food _producing_animals.pdf)

Darwish WS, Eldaly EA, El-Abbasy MT, Ikenaka Y, Nakayama S et al., 2013. Antibiotic residues in food: The African scenario. Japanese J Vet Res, 61(suppl): S13-S22

Davies J and Davies D, 2010. Origins and evolution of antibiotic resistance. Microbiol Mol Biol Rev, 74(3): 417-433

Denev SA, 2006. Effect of different growth promoters on the cecal microflora and performance of broiler chickens. Bulgarian J Agricul Sci, 12:461-467

Dennis SM, Nagaraja TG and Bartley EE, 1981. Effect of lasalocid or monensin on lactateproducing or using rumen bacteria. J Anim Sci, 52: 418-426

Dibner JJ and Richards JD, 2005. Antibiotic growth promoters in agriculture: history and mode of action. Poult Sci, 84: 634-643

Dinius DA, Simpson ME and Marsh PB, 1976. Effect of monensin fed with forage on digestion and the ruminal ecosystem of steers. J Anim Sci, 42: 229-234

Drug Controller General of India, 2013. Drugs and Cosmetics Act https://cdsco.gov.in/opencms/ opencms/system/modules/CDSCO.WEB/ elements/download_file_division.jsp? num_id = Mjcx

EC, 2012. European Commission. Commission staff working document on the implementation of national residue monitoring plans in the member states in 2009 (Europian Union Council Directive 96/23/EC) 
EMA Committee for Medicinal Products for Veterinary Use (CVMP) and EFSA Panel on Biological Hazards (BIOHAZ), Murphy D, Ricci A, Auce Z, Beechinor JG, Bergendahl H and Hekman P, 2017. EMA and EFSA Joint Scientific Opinion on measures to reduce the need to use antimicrobial agents in animal husbandry in the European Union, and the resulting impacts on food safety (RONAFA). EFSA J, 15: e04666

Eseceli M, Demir E, Degirmencioglu N and Bilgic M, 2010. The Effects of Bio-Mos ${ }^{\circledR}$ mannan oligosaccharide and antibiotic growth promoter performance of broilers. J Anim Vet Adv, 9: 392-395

Fischer J, Rodríguez I, Schmoger S, Friese A, Roesler U et al., 2012. Escherichia coli producing VIM1 carbapenemase isolated on a pig farm. J Antimicrob Chemoth, 67: 1793-1795

Food and Agriculture Organization of the United Nations (FAO), 2015. Status Report on Antimicrobial Resistance. Rome: Food and Agriculture Organization of the United Nations

Food and Agriculture Organization of the United Nations (FAO), 2016. Gateway to poultry production and products. Rome: Food and Agriculture Organization of the United Nations

Food and Drug Administration, 2010. Report of Food and Drug Administration, FDA, USA

Food and Drug Administration, 2013. Phasing out certain antibiotic use in farm animals, FDA, USA, https://www.fda.gov/ForConsumers/ ConsumerUpdates/ucm378100.htm

FSSAI, 2011. Food Safty and Stndards Authority of India, http://fsdaup.gov.in/ writereaddata/ images/pdf/act-and-rules/fss-regulation/Foodsafety-and-standards-contaminats-toxins-andresidues-regulation-2011.pdf

FSSAI, 2015. Food Safty and Stndards Authority of India, http://old.fssai.gov.in/ Portals/0/Pdf/ Draft_Meat_Poultry_Comments.pdf
Gaskins HR, Collier CT and Anderson DB, 2002. Antibiotics as growth promotants: mode of action. Anim Biotechnol, 13: 29-42

Ghafur A, Shankar C, Gnana Soundari P, Venkatesan M, Mani D et al., 2019. Detection of chromosomal and plasmid-mediated mechanisms of colistin resistance in Escherichia coli and Klebsiella pneumoniae from Indian food samples. J Glob Antimicrob Resist, 16: 48-52

Goetting V, Lee KA and Tell LA, 2011. Pharmacokinetics of veterinary drugs in laying hens and residues in eggs: A review of the literature. J Vet Pharmacol Therapy, 34: 521556

Graham JP, Boland JJ and Silbergeld E, 2007. Growth promoting antibiotics in food animal production: An economic analysis. Public Health Rep, 122: 79-87

Gupta S, Mohini M, Malla BA, Mondal G and Pandita S, 2019. Effects of monensin feeding on performance, nutrient utilisation and enteric methane production in growing buffalo heifers. Trop Anim Health Prod, 51: 859-866

Hugo WB and Russel AD, 1998. Pharmaceutical Microbiol. 6th edn., Oxford: Blackwell Science Ltd pp514

Hume ME, 2011. Historic perspective: prebiotics, probiotics, and other alternatives to antibiotics. Poult Sci, 90: 2663-2669

Huyghebaert G, Ducatelle R and Van Immerseel F, 2011. An update on alternatives to antimicrobial growth promoters for broilers. The Vet J, 187: 182-188

JETACAR, 1999. Report of the Joint Expert Technical Advisory Committee on Antibiotic Resistance, 1999. The Department of Health, Australian Government

Johnson KA and Johnson DE, 1995. Methane emissions from cattle. J Anim Sci, 73: 2483-2492 
Katz SE and Brady MS, 2000. Antibiotic residues in food and their significance. Food Biotechnol, 14: 147-171

Khurana S, Mathur P, Kapil A, Valsan C and Behera B, 2017. Molecular epidemiology of betalactamase producing nosocomial gramnegative pathogens from North and South Indian hospitals. J Med Microbiol, 66: 9991004

Landers TF, Cohen B, Wittum TE and Larson EL, 2012. A review of antibiotic use in food animals: Perspective, policy, and potential. Public Health Rep,127: 4-22

Madigan MT, Martinko JM, Bender KS, Buckley FH and Stahl DA, 2014. Brock Biology Microorganisms, $14^{\text {th }}$ edn., Illinois: Pearson International, pp1006

Mahalmani VM, Sarma P, Prakash A and Medhi B, 2019. Positive list of antibiotics and food products: Current perspective in India and across the globe. Indian J Pharmacol, 51: 231

Markovic R, Sefer D, Krsti M and Petrujki B, 2009. Effect of different growth promoters on broiler performance and gut morphology. Archivos de Medicina Veterinaria, 41: 163-169

Mellon M, Benbrook C and Benbrook KL, 2001. Hogging It! Estimates of Antimicrobial Abuse in Livestock. Union of Concerned Scientists: Cambridge, MA, January, http:// www.ucsusa.org/assets/documents/food_ and_agriculture/hog_chaps.pdf

Mirlohi M, Aalipour F and Jalali M, 2013. Prevalence of antibiotic residues in commercial milk and its variation by season and thermal processing methods. Int J Environ Health Eng, 2: 41

Muaz K, Riaz M, Akhtar S, Park S and Ismail A, 2018. Antibiotic residues in chicken meat: global prevalence, threats, and decontamination strategies: A review. J food protect, 81: 619-627
Nagaraja TG and Chengappa MM, 1998. Liver abscesses in feedlot cattle: A review. J Anim Sci, 76: 287-298

Naveen KS, Karthikeyan N, Babu RN, Veeramani P and Sivarama Krishna S, 2017. Effect of organic acid salts as an alternative to antibiotic growth promoters on the production performance of commercial broiler chicken. Inter J Curr Microbiol and Appl Sci, 9: 34703480

Niewold TA, 2007. The nonantibiotic antiinflammatory effect of antimicrobial growth promoters, the real mode of action? A hypothesis. Poult Sci, 86: 605-609

Nisha AR, 2008. Antibiotic residues-a global health hazard. Vet World, 1: 375

National Livestock Policy, 2013. http:// dahd.nic.in/sites/default/filess/ NLP\%202013\% 20Final11.pdf

NPCAR, 2011. National policy for containment of antimicrobial resistance. New Delhi: MoHFW; Directorate General of Health Services. Ministry of Health and Family Welfare

NPCAR, 2012. National Programme on Containment of AMR (2012) http:// dghs.gov.in/ WriteReadData/ userfiles/file/ National_Programme_on_Containment_of_Anti_ Microbial_Resistance.pdf

NPCAR, 2017. National Policy on Containment of AMR, http://www.searo.who.int/ india/topics/ antimicrobial_resistance/nap_amr.pdf

Postma M, Vanderhaeghen W, Sarrazin S, Maes D and Dewulf J, 2017. Reducing antimicrobial usage in pig production without jeopardizing production parameters. Zoonosis Public Health, 64: 63-74

Price LB, Stegger M, Hasman H, Aziz M, Larsen J et al., 2012. Staphylococcus aureus CC398: host adaptation and emergence of methicillin resistance in livestock. MBio, 3: e00305-00311 
Qumar S, Majid M, Kumar N, Tiwari SK, Semmler T et al., 2017. Genome dynamics and molecular infection epidemiology of multidrug-resistant Helicobacter pullorum isolates obtained from broiler and free-range chickens in India. Appl Environ Microbiol, 83: e02305-2316

Russell JB and Strobel HJ, 1989. Effect of ionophores on ruminal fermentation. App Environ Microbiol, 55: 1-6

Sahoo KC, Tamhankar AJ, Johansson E and Lundborg CS, 2010. Antibiotic use, resistance development and environmental factors: A qualitative study among healthcare professionals in Orissa, India. BMC Public Health, 10: 629

Stokstad ELR, Jukes TH, Pierce J, Page Jr AC and Franklin AL, 1949. The multiple nature of the animal protein factor. J Biol Chem, 180: 647-654

Swann MM, 1969. Report: Joint Committee on the Use of Antibiotics Volume I. Technical Report. Washington, D.C.: Congress of the Animal Husbandry and Veterinary Medicine. London, UK: United States, US Government Printing Office, HMSO

Taylor DJ, 1999. The pros and cons of antimicrobial use in animal husbandry. Bailliere's Clin Infect Dis, 5: 269-287

Tedeschi LO, Fox DG and Tylutki TP, 2003. Potential environmental benefits of ionophores in ruminant diets. J Environ Quality, 32: 1591-1602

Tian L, Khalil S and Bayen S, 2017. Effect of thermal treatments on the degradation of antibiotic residues in food. Crit Rev Food Sci Nutr, 57: 3760-3770

Thomke S and Elwinger K,1998. Growth promotants in feeding pigs and poultry. I.
Growth and feed efficiency responses to antibiotic growth promotants. Annales de zootechnie, 47: 85-97

United States Department of Agriculture, 2014. Antimicrobial resistance action plan, https:// www.usda.gov/sites/default/files/documents/ usda-antimicrobial-resistance-actionplan.pdf

Van Boeckel TP, Brower C, Gilbert M, Grenfell BT, Levin SA et al., 2015. Global trends in antimicrobial use in food animals. Proc Natl Acad Sci USA, 112: 5649-5654

Willis C, 2000. Antibiotics in the food chain: their impact on the consumer. Rev Med Microbiol, 11: 153-160

World Health Organization (WHO), 1997. WHO global strategy for containment of antimicrobial resistance. WHO, Geneva, WHO/ CDS/CSR/DRS/2001.2

World Health Organization (WHO), 2014. Antimicrobial Resistance Global Report on Surveillance, WHO, Geneva, 256, (http:// www.who.int/drugresistance/documents/ surveillancereport/en/)

World Health Organization (WHO), 2015. Worldwide Country Situation Analysis: Response to Antimicrobial Resistance. World Health Organization, Geneva

Yates AB and deShazo RD, 2003. Allergic and nonallergic drug reactions. Southern Med J, 96: 1080-1088

Zhang QQ, Ying GG, Pan CG, Liu YS and Zhao JL, 2015. Comprehensive evaluation of antibiotics emission and fate in the river basins of China: source analysis, multimedia modeling, and linkage to bacterial resistance. Environ Sci Technol, 49: 6772-6782 